\title{
IDENTIFIKASI RUANG LINGKUP MASALAH GURU IPA DALAM MENGAJAR MATERI BIOLOGI DI SEKOLAH MENENGAH PERTAMA (SMP) NEGERI KOTA BINJAI
}

\author{
Dewi Rulia Br Sitepu, S.Pd., M.Si
}

\section{Dosen Sekolah Tinggi Keguruan dan Ilmu Pendidikan (STKIP) Budidaya \\ Email : dewiruliasitepu@gmail.com}

\begin{abstract}
ABSTRAK
Penelitian ini bertujuan untuk mengidentifikasi ruang lingkup masalah dalam mengajar materi Biologi yang tidak sesuai dengan spesialisnya di SMP Negeri di Kota Binjai. Jenis penelitian yang digunakan adalah deskriptif kualitatif dengan metode survey (angket). Teknik analisis yang digunakan adalah teknik analisis deskriptif persentase. Hasil penelitian mengenai latar belakang pendidikan guru menunjukkan bahwa guru IPA didominasi oleh lulusan Sarjana Biologi. Hal ini sangat mendukung konten materi IPA SMP yang memiliki landasan (platform) dari konsep-konsep biologi, walaupun demikian IPA terpadu yang diajarkan di SMP menuntut guru untuk memahami dan mengintegrasikan dengan baik konsep-konsep Fisika, Kimia, Bumi dan Antariksa. Guru yang berasal dari bukan kelompok IPA atau bukan spesialisasinya dalam mengajarkan IPA mengalami kesulitan yang lebih tinggi ( spesialisasi BP dengan 79,05\%) dibandingkan dengan guru yang berasal dari kelompok IPA yaitu spesialisasi Biologi dengan 49,92\%. Faktor penyebab guru mengalami kesulitan dalam mengajar materi Biologi yaitu kualifikasi dan latar belakang pendidikan tidak sesuai dengan bidang tugasnya, tidak memiliki kompetensi yang diperlukan sesuai bidang tugas, kurangnya kesempatan untuk mengembangkan profesi secara berkelanjutan, persoalan rambu-rambu atau acuan pelaksanaan, arah kebijakan pendidikan, paradigma sistem pendidikan, termasuk sistem dan kurikulum yang selalu mengalami perubahan, sistem yang selama ini digunakan oleh guru masih monoton sehingga berpengaruh terhadap pola pikir siswa.
\end{abstract}

Kata kunci : Masalah Guru IPA Terpadu, Mengajar materi Biologi, Kesulitan Mengajar

\section{PENDAHULUAN}

Guru IPA harus memahami dengan baik isi materi (konten) yang akan diajarkan dan cara mengajarkannya. Mereka juga harus paham dan mampu dalam mengintegrasikan pengetahuan ke dalam kurikulum dan pembelajaran IPA. Penguasaan konten dan proses pembelajaran dapat menuntun guru untuk merangkai situasi pembelajaran sesuai kebutuhan individu siswa maupun kelompok (Purwianingsih, dkk., 2010). Pengetahuan seperti ini dinyatakan sebagai pengetahuan konten pedagogi (pedagogical content knowledge/PCK). PCK menurut Cochran, dkk. (1993) meliputi pemahaman guru tentang isi materi/konten, pengetahuan pedagogi, dan cara membelajarkan konten yang mudah maupun sulit kepada para siswanya agar mereka mau belajar dengan baik.

Pengetahuan senantiasa berkembang seiring perkembangan jaman, guru dituntut untuk terus belajar memutakhirkan keilmuannya. Terbatasnya pengetahuan guru 


\section{Jurnal Serunai Ilmu Pendidikan \\ Vol.6, No.1, Juni 2020 \\ e-ISSN $2621-2676$ \\ p-ISSN 2528 - 0775}

menjadi kendala yang besar dalam usaha membelajarkan konten IPA yang perkembangannya senantiasa terbarukan. Selama ini dalam membelajarkan konten IPA, guru juga menghadapi berbagai kendala seperti ketersediaan sumber belajar yang kurang mendukung atau penerapan strategi pembelajaran yang belum efektif. Kesulitan yang dialami guru adalah pemicu lahirnya ketidakberhasilan pembelajaran pada siswa dan memunculkan pandangan bahwa IPA merupakan mata pelajaran yang sulit (Unesco, 2010).

Proses belajar mengajar pada hakekatnya adalah proses komunikasi, yaitu proses penyampaian pesan dari sumber pesan melalui saluran. Pesan berupa isi ajaran dan didikan yang ada dikurikulum dituangkan oleh guru atau sumber lain ke dalam simbol-simbol komunikasi berupa simbol verbal maupun non verbal. Dalam mempelajari biologi bukan semata-mata hanya menghapal tetapi harus memahami konsep-konsep dasarnya, karena pelajaran biologi serba kompleks dan memerlukan nalar yang tinggi untuk menganalisanya (Afni, 2019). Dalam Sitepu (2017) menyatakan bahwa untuk meningkatkan mutu pendidikan salah satunya maka guru harus mampu membuat perencanaan pembelajaran, proses pelaksanaan pembelajaran dan penilaian hasil belajar yang baik dan ini akan terwujud bila guru memenuhi kualifikas seperti yang diinginkan Peraturan Pemerintah No 19 tahun 2005 pada Standart Nasional Pendidikan dan Permendiknas no 16 Tahun 2007 tentang Standar Pendidik dan Tenaga Kependidikan yang menyebutkan guru harus berpendidikan minimal Sarjana / Diploma IV dan mengajar mata pelajaran harus sesuai dengan latar belakang pendidikannya atau spesialisnya.
Setiap materi pelajaran tentu memiliki tingkat kesukaran yang bervariasi (Sitepu, 2019) yang berdampak pada kesulitan belajar terhadap siswa. Kemampuan guru dalam menjelaskan materi Biologi harus menjadi titik utama dalam mencapai keberhasilan belajar siswa. Salah satu indikator kesulitan siswa dalam belajar adalah ketidakmampuan anak untuk menampakkan salah satu dari beberapa kemampuan akademik. Kemampuan ini menyangkut aspek kognitif, afektif dan psikomotor (Depdiknas, 2003).

Penelitian ini merupakan langkah awal untuk mengidentifikasi kesulitan pembelajaran IPA dan Upaya mengatasi permasalahan yang dihadapi oleh guru IPA SMP di Kota Binjai. Informasi yang diperoleh penting untuk mengetahui konsep yang sulit dipahami dan belum dipahami dengan baik, sehingga dapat menentukan pemilihan strategi pembelajaran yang tepat untuk mencegah kesulitan tersebut terjadi kembali. SMP memiliki struktur kurikulum sesuai dengan Permendiknas No. 22 Tahun 2006 meliputi substansi pembelajaran yang ditempuh dalam satu jenjang pendidikan selama tiga tahun mulai kelas VII sampai dengan kelas IX. Substansi mata pelajaran IPA pada SMP merupakan IPA Terpadu dimana pada mata pelajaran tersebut terdapat materi Biologi, Kimia, dan Fisika.

Untuk meningkatkan mutu pendidikan pada bidang IPA Terpadu maka guru harus mampu membuat perencanaan pembelajaran, proses pelaksanaan pembelajaran dan penilaian hasil belajar yang baik dan ini akan terwujud bila guru memenuhi kualifikasi seperti yang diinginkan Peraturan Pemerintah No 19 tahun 2005 pada Standart Nasional Pendidikan dan Permendiknas no 16 Tahun 2007 tentang Standar Pendidik dan Tenaga Kependidikan yang menyebutkan guru harus berpendidikan minimal Sarjana / Diploma IV dan mengajar 
mata pelajaran harus sesuai dengan latar belakang pendidikannya atau spesialisnya. Kenyataannya sarjana / Diploma IV IPA Terpadu terpadu masih kurang untuk mengajar di SMP sesuai tuntutan KTSP dan ironisnya Universitas Negeri Medan sebagai salah satu Perguruan Tinggi pencetak tenaga guru di Sumatera Utara belum menyediakan jurusan atau spesialis IPA Terpadu Program Sarjana / Diploma IV sehingga berdampak terhadap mutu pendidikan.

\section{METODE PENELITIAN}

Penelitian ini dilaksanakan di SMP Negeri Kota Binjai. Populasi penelitian ini adalah seluruh guru IPA Terpadu sebanyak 81 orang yang mengajar di 12 sekolah SMP Negeri Kota Binjai. Sampel diambil secara total sampling, hal ini sesuai dengan pernyataan Arikunto ( 2009 ) yaitu sampel yang mewakili jumlah populasi dan biasanya dilakukan jika populasi dianggap kecil atau kurang dari 100. Sampel yang diambil berjumlah 81 orang guru IPA Terpadu.

Untuk memperoleh data yang diperlukan dalam penelitian ini maka digunakan instrumen pengumpul data yaitu angket dan survey. Angket penelitian memuat pertanyaan-pertanyaan yang berkaitan dengan kompetensi yang mengacu pada standar kompetensi dan kompetensi dasar IPA. Angket yang digunakan untuk guru IPA Terpadu berupa angket tertutup atau berstruktur yang disusun berupa pernyataan disertai alternative jawaban. Alternatif jawaban terdiri dari 4 option dengan menggunakan skala Likert. Skala Likert merupakan suatu instrument pengukuran sikap yang terdiri dari satu daftar pernyataan, seseorang yang merespon harus membuat pertimbangan terhadap setiap pernyataan dan memilih suatu respon dari tingkat sesuai sampai ke tingkat tidak sesuai. Angket diberikan langsung kepada responden yang disertai ijin resmi dari instansi terkait. Hasil dan jawaban angket kemudian dirubah dalam bentuk angka tiap option dan diberi pembobotan. Sumber yang digunakan dalam penyusunan instrument angket yaitu Permendiknas Nomor 41 Tahun 2007 tentang Standar Proses, Permendiknas Nomor 20 Tahun 2007 Tentang Penilaian, Badan Standar Nasional Pendidikan 2006, dan Teknik Analisis Butir Soal, Instrumen Tes, dan Non Tes.

Teknik analisis yang digunakan adalah teknik analisis deskriptif persentase. Teknik ini digunakan untuk mengetahui kesulitan mengajar guru IPA Terpadu.

Rumus yang digunakan (Arikunto, 2009) adalah:

$$
\%=\frac{f}{N} X 100 \%
$$

Keterangan :

$$
\begin{aligned}
& \mathrm{f}=\text { skor observasi yang dicapai } \\
& \mathrm{N}=\text { skor ideal } \\
& \%=\text { tingkat persentase yang } \\
& \text { diperoleh }
\end{aligned}
$$

\section{HASIL PENELITIAN DAN PEMBAHASAN}

Jumlah angket yang disebarkan kepada guru IPA Terpadu adalah sebanyak 81 angket sedangkan angket yang kembali sebanyak 75 angket dari seluruh guru dan hanya 71 angket yang digunakan karena sesuai dengan kualifikasi yang tertera pada Peraturan Pemerintah No 19 tahun 2005 pada Standart Nasional Pendidikan dan Permendiknas no 16 Tahun 2007 tentang Standar Pendidik dan Tenaga Kependidikan, dimana terdapat 4 angket tidak sesuai dengan kualifikasi atau masih dibawah S1/D4. Data penyebaran angket dapat dilihat pada table 1 . 
Tabel 1. Data Populasi guru IPA Terpadu di SMP Negeri Kota Binjai

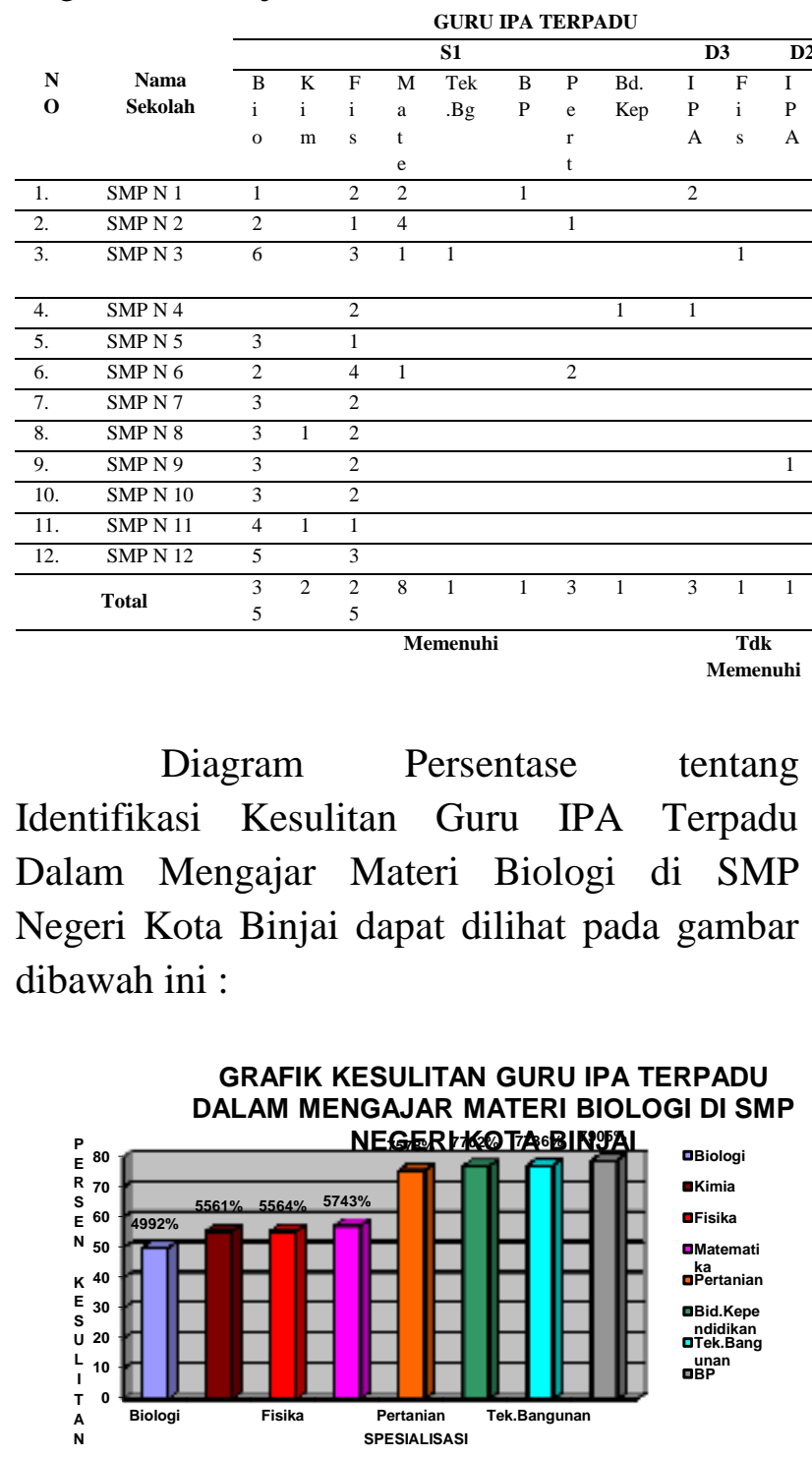

Gambar 1. Diagram Kesulitan Guru IPA Terpadu Dalam Mengajar Materi Biologi Di SMP Negeri Kota Binjai

Dari hasil penelitian yang telah dipaparkan bahwa kesulitan guru IPA Terpadu dalam mengajar materi Biologi untuk guru spesialis Biologi dengan tingkat kesulitan kategori sedang $(49,92 \%)$, Kimia dengan kategori sedang $(55,61 \%)$, Fisika dengan kategori sedang $(55,64 \%)$, Matematika dengan kategori sedang $(57,43 \%)$, Pertanian dengan kategori tinggi (75,78\%), Bidang Kependidikan dengan kategori tinggi (77,02\%), , Teknik
Bangunan dengan kategori tinggi (77,36\%), dan BP dengan kategori tinggi $(79,05 \%)$ yang mengajar IPA terpadu mengalami kesulitan I dalam melaksanakan pembelajaran dan yang sangat kesulitan adalah guru yang bukan ${ }_{8}^{8}$ kelompok IPA.

Standar Kompetensi Guru ini dikembangkan secara utuh dari empat kompetensi utama, yaitu kompetensi pedagogik, kepribadian, sosial, dan profesional. Kompetensi Guru mata pelajaran IPA Terpadu ${ }_{8}^{6}$ pada SMP adalah pada tabel berikut :

Tabel 2. Kompetensi Guru mata pelajaran IPA Terpadu pada SMP

\begin{tabular}{ll} 
No & \multicolumn{1}{c}{ Kompetensi Guru IPA Terpadu } \\
\hline 1. & $\begin{array}{l}\text { Memahami konsep-konsep, hukum-hukum, dan teori-teori IPA serta } \\
\text { penerapannya secara fleksibel }\end{array}$ \\
\hline 2. & $\begin{array}{l}\text { Memahami proses-proses berpikir IPA dalam mempelajari proses dan } \\
\text { gejala alam }\end{array}$ \\
\hline 3. & $\begin{array}{l}\text { Menggunakan bahasa simbolik dalam mendeskripsikan proses dan gejala } \\
\text { alam }\end{array}$ \\
\hline 4. & $\begin{array}{l}\text { Memahami hubungan antar berbagai cabang IPA dan hubungan IPA } \\
\text { dengan matematika dan teknologi }\end{array}$ \\
\hline 5. & $\begin{array}{l}\text { Bernalar secara kualitatif maupun kuantitatif tentang proses dan hukum } \\
\text { alam sederhana }\end{array}$ \\
\hline 6. & $\begin{array}{l}\text { Menerapkan konsep, hukum, dan teori IPA untuk menjelaskan berbagai } \\
\text { fenomena alam }\end{array}$ \\
\hline 7. & $\begin{array}{l}\text { Menjelaskan penerapan hukum-hukum IPA dalam eknologi terutama } \\
\text { yang dapat ditemukan dalam kehidupan sehari-hari }\end{array}$ \\
\hline 8. & Memahami lingkup dan kedalaman IPA sekolah \\
\hline 9. & Kreatif dan inovatif dalam penerapan dan pengembangan IPA \\
\hline 10. & $\begin{array}{l}\text { Menguasai prinsip-prinsip dan teori-teori pengelolaan dan keselamatan } \\
\text { kerja/belajar di laboratorium sekolah }\end{array}$ \\
\hline 11. & $\begin{array}{l}\text { Menggunakan alat-alat ukur, alat peraga, alat hitung, dan piranti lunak } \\
\text { komputer untuk meningkatkan pembelajaran IPA di kelas, laboratorium }\end{array}$ \\
\hline 12. & $\begin{array}{l}\text { Merancang eksperimen IPA untuk keperluan pembelajaran atau } \\
\text { penelitian }\end{array}$ \\
\hline 13. & Melaksanakan eksperimen IPA dengan cara yang benar \\
\hline 14. & $\begin{array}{l}\text { Memahami sejarah perkembangan IPA dan pikiran-pikiran yang } \\
\text { mendasari perkembangan tersebut }\end{array}$ \\
&
\end{tabular}
( Permendiknas No.16, 2007)

Pada waktu melaksanakan pembelajaran masih banyak guru yang mengalami kesulitan mengajar mata pelajaran yang diampunya. Hal ini terjadi karena guru yang mengajar tersebut :

1. Kualifikasi dan latar belakang pendidikan tidak sesuai dengan bidang tugasnya. Dilapangan banyak di antara guru mengajarkan mata pelajaran yang tidak sesuai dengan kualifikasi dan latar belakang pendidikan yang dimiliki.

2. Tidak memiliki kompetensi yang diperlukan sesuai bidang tugas. Guru 
profesional seharusnya memiliki empat kompetensi, yaitu kompetensi pedagogis, kognitif, personaliti, dan sosial. Oleh karena itu, seorang guru selain terampil mengajar, juga memiliki pengetahuan yang luas, bijak, dan dapat bersosialisasi dengan baik.

3. Kurangnya kesempatan untuk mengembangkan profesi secara berkelanjutan. Banyak guru yang terjebak pada rutinitas. Pihak berwenang pun tidak mendorong guru ke arah pengembangan kompetensi diri ataupun karier. Hal itu terindikasi dengan minimnya kesempatan beasiswa yang diberikan kepada guru dan tidak adanya program pencerdasan guru, misalnya dengan adanya tunjangan buku referensi, dan pelatihan berkala. Profesionalisme dalam pendidikan perlu dimaknai " he does his job well". Artinya, guru haruslah orang yang memiliki insting pendidik, paling tidak mengerti dan memahami peserta didik. Guru harus menguasai secara mendalam minimal satu bidang keilmuan. Guru harus memiliki sikap integritas profesional. Dengan integritas barulah, sang guru menjadi teladan atau role model.

4. Masih sangat banyak guru yang memiliki kompetisi rendah dan memprihatinkan.

5. Masih banyak guru di Indonesia yang kurang terpacu dan termotivasi untuk memberdayakan diri, mengembangkan profesionalitas diri atau memutakhirkan pengetahuan mereka secara terus-menerus dan berkelanjutan, meskipun cukup banyak guru Indonesia yang sangat rajin menaikkan pangkat mereka dan sangat rajin pula mengikuti program-program pendidikan kilat atau jalan pintas yang dilakukan oleh berbagai lembaga pendidikan.
6. Masih banyak guru Indonesia yang kurang terpacu, terdorong, dan tergerak secara pribadi untuk mengembangkan profesi mereka sebagai guru.

7. Persoalan rambu-rambu atau acuan pelaksanaan, arah kebijakan pendidikan, paradigma sistem pendidikan, termasuk sistem dan kurikulum yang selalu mengalami perubahan.

8. Semakin cepatnya perkembangan teknologi sehingga menuntut guru lebih proaktif terhadap perkembangan tersebut.

9. Kesempatan guru yang sangat terbatas dalam mengembangkan kemampuannya.

10. Sistem yang selama ini digunakan oleh guru masih monoton sehingga berpengaruh terhadap pola pikir siswa.

(IPA Terpadu Hadapi Tantangan,2010)

Sesuai Permendiknas Nomor 41 Tahun 2007 tentang standart proses dan Permendiknas Nomor 20 Tahun 2007 tentang penilaian menyebutkan bahwa seorang guru harus membuat perencanaan proses pembelajaran, melaksanaan proses pembelajaran dan menilai proses pembelajaran maka seorang guru harus membuat perangkat pembelajaran. Adapun perangkat pembelajaran yang harus direncanakan, dilaksanakan dan dinilai yaitu seperti pada table 3 berikut :

Tabel 3. Perangkat Pembelajaran yang direncanakan, dilaksanakan, dan dinilai

\begin{tabular}{cl} 
No. & \multicolumn{1}{c}{$\begin{array}{c}\text { Perangkat Pembelajaran yang direncanakan, } \\
\text { dilaksanakan, dan dinilai }\end{array}$} \\
\hline 1. & Kalender mata pelajaran \\
\hline 2. & Program Tahunan ( Prota ) \\
\hline 3. & Program Semester ( Prosem ) \\
\hline 4. & Silabus yang dikembangkan \\
\hline 5. & Kriteria Ketuntasan Minimal ( KKM ) \\
\hline 6. & Rencana Pelaksaanaan Pembelajaran (RPP) \\
\hline 7. & Butir soal ulangan harian \\
\hline 8. & Nilai ulangan harian setiap Kompetensi Dasar ( KD ) \\
\hline 10. & Analisis soal butir harian \\
\hline 11. & Analisis ketuntasan setiap Kompetensi Dasar \\
\hline 12. & Program remedial dan pengayaan \\
\hline 13. & Kilai remedial/ pengayaan setiap Kompetensi Dasar \\
\hline 14. & Butir soal ulangan tengah semester \\
\hline 15. & Ulangan tengah semester ( UTS )
\end{tabular}


Nilai ulangan tengah semester

Analisis nilai ulangan tengah semester

Program bimbingan studi setiap mata pelajaran

Kisi-kisi ulangan semester gasal

20. Butir soal ulangan semester gasal

21. Analisis nilai ulangan semester

22. Kisi-kisi ulangan semester genap ( ulangan kenaikan kelas )

23. Butir soal ulangan semester genap

24. Nilai ulangan semester genap ( ulangan kenaikan kelas )

Media pembelajaran sesuai RPP

( Permendiknas No.41 dan 20, 2007 ).

Faktor kesulitan guru IPA Terpadu yang tidak sesuai dengan spesialisnya mengajar merupakan suatu keadaan atau kondisi guru yang dampaknya guru kurang profesional dalam menyampaikan pembelajaran kepada peserta didik sehingga tujuan dalam pembelajaran tidak tercapai dan dapat megakibatkan rendahnya mutu pendidikan yang diakibatkan karena guru IPA Terpadu yang mengajar terdiri dari tiga spesialis yaitu guru spesialis Biologi, guru spesialis Kimia, dan guru spesialis Fisika.

Oleh karena meningkatkan mutu pendidikan guru harus profesional sesuai program studi atau sertifikat pendidik yang dimilikinya maka guru IPA Terpadu yang mengajar tidak sesuai dengan spesialisnya kurang profesional.

Salah satu factor yang dapat mempengaruhi adalah matakuliah yang dikuasai pada saat perkuliahan. Persentase daftar mata kuliah Kimia, Fisika, dan Biologi dari spesialis masing-masing ditampilkan pada table dibawah ini yaitu sebagai berikut :

Tabel 4. Persentase Daftar Mata Kuliah Biologi, Kimia, dan Fisika dari masing-masing spesialis.

\begin{tabular}{lllr} 
No & \multicolumn{1}{c}{ Spesialis } & \multicolumn{1}{c}{ Mata Kuliah } & Persen ( \%) \\
\hline \multirow{2}{*}{1.} & Biologi & Biologi & $59,42 \%$ \\
\cline { 3 - 4 } & & Kimia & $5,79 \%$ \\
\cline { 3 - 4 } & & Fisika & $5,79 \%$ \\
\hline 2. & \multirow{2}{*}{ Kimia } & Biologi & $4,68 \%$ \\
\cline { 3 - 4 } & & Kimia & $57,81 \%$ \\
\cline { 3 - 4 } & & Fisika & $6,25 \%$ \\
\hline 3. & Fisika & Biologi & $5,08 \%$ \\
\cline { 3 - 4 } & & Kimia & $6,77 \%$ \\
\cline { 3 - 4 } & & Fisika & $54,23 \%$
\end{tabular}

Dari persentase daftar mata kuliah spesialis Biologi diatas, latar belakang Guru IPA Terpadu spesialis Biologi hanya mampu menguasai pada bidangnya saja dikarenakan minimnya kuliah pada mata kuliah Kimia dan Fisika. Sedangkan mata pelajaran IPA Terpadu mewajibkan guru untuk membahas pelajaran kimia dan fisika sesuai Standar Kompetensi yang ingin dicapai sehingga guru mengalami kesulitan dalam mengajarkannya. Kesulitan atau ketidakmampuan guru spesialis Biologi mengajarkan kimia dan fisika akan menyebabkan guru spesialis tersebut akan mengajarkan materi- materi biologi yang sesuai dengan kemampuannya yang akan membuat peserta didik tidak memiliki prestasi belajar dalam hal kimia dan fisika.

Guru spesialis Kimia memiliki kesulitan dalam mengajarkan materi Biologi, hal ini dikarenakan mata kuliah yang menjadi latar belakangnya jauh dari kompetensi dasar yang akan dicapai pada matapelajaran IPA Terpadu materi Biologi. Misalnya saja pada Kompetensi dasar mendeskripsikan tahapan perkembangan manusia. Guru spesialis kimia akan mengalami kesulitan dalam mengajarkan kompetensi tersebut karena kompetensi tersebut lebih cenderung berada pada mata kuliah jurusan Biologi. Kesulitan yang dihadapi guru spesialis kimia tersebut mengimplikasikan rendahnya prestasi belajar peserta didik pada kompetensi tersebut.

Sedangkan kemampuan yang dimiliki oleh guru IPA Terpadu spesialis Fisika tidak lain hanya sebata ruang lingkup fisika. Jauh kemungkinan Guru fisika akan mampu mengajarkan materi Biologi dan Kimia. Kesulitan ini dapat dilihat dari Standar Kompetensi yang wajibkan pada materi biologi tentang sistem reproduksi, dimana guru spesialis fisika akan mengalami kesulitan dalam mengajarkan dan menjelaskan mengenai 


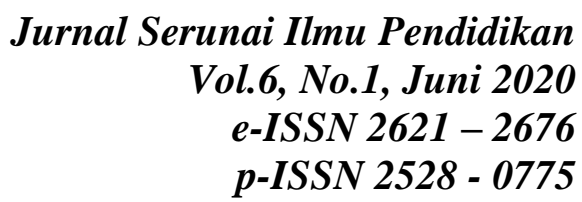

materi tersebut. Materi Biologi lebih terfokus pada bagian makhluk hidupnya dan materi Kimia terfokus oleh zat dan wujudnya, dari kedua materi ini saling berhubungan dalam bidang laboratorium Biokimia. Sedangkan pada materi Fisika lebih fokus pada alat-alat yang bekerja pada laboratorium. Disini hal yang sangat sulit untuk dipahami dan dimengerti seorang guru IPA Terpadu spesialis Fisika mengajarkan IPA Terpadu kepada peserta didiknya.

Hasil penelitian mengenai latar belakang pendidikan guru menunjukkan bahwa guru IPA didominasi oleh lulusan Sarjana Biologi. Hal ini sangat mendukung konten materi IPA SMP yang memiliki landasan (platform) dari konsep-konsep biologi, walaupun demikian IPA terpadu yang diajarkan di SMP menuntut guru untuk memahami dan mengintegrasikan dengan baik konsep-konsep Fisika, Kimia, Bumi dan Antariksa. Hambatan latar belakang pendidikan tersebut sangat mungkin mempengaruhi tingkat penguasaan guru dalam mengajarkan konten suatu mata pelajaran sehingga berdampak kepada kemampuan penguasaan siswa (Buddin dan Zamarro, 2009).

\section{SIMPULAN}

Berdasarkan hasil penelitian dan pembahasan maka dapat ditarik kesimpulan sebagai berikut:

1. Guru yang berasal dari bukan kelompok IPA atau bukan spesialisasinya dalam mengajarkan IPA mengalami kesulitan yang lebih tinggi ( spesialisasi BP dengan $79,05 \%$ ) dibandingkan dengan guru yang berasal dari kelompok IPA yaitu spesialisasi Biologi dengan 49,92\%.

2. Faktor penyebab guru mengalami kesulitan dalam mengajar materi Biologi yaitu kualifikasi dan latar belakang pendidikan tidak sesuai dengan bidang tugasnya, tidak memiliki kompetensi yang diperlukan sesuai bidang tugas, kurangnya kesempatan untuk mengembangkan profesi secara berkelanjutan, persoalan ramburambu atau acuan pelaksanaan, arah kebijakan pendidikan, paradigma sistem pendidikan, termasuk sistem dan kurikulum yang selalu mengalami perubahan, sistem yang selama ini digunakan oleh guru masih monoton sehingga berpengaruh terhadap pola pikir siswa.

3. Upaya mengatasi kesulitan dalam mengajar materi Biologi bila tidak sesuai dengan spesialisnya di SMP Negeri Kota Binjai yaitu harus mendiskusikannya dengan kepala sekolah, pengawas sekolah, melaksanakan Musyawarah Guru Mata Pelajaran (MGMP), melanjutkan pendidikan ke jenjang yang lebih tinggi yang sesuai dengan spesialisnya, melakukan team teaching, mengikuti seminar-seminar, mengikuti pendidikan dan pelatihan (Diklat), memanfaatkan IT, mengadakan workshop, mengkondisikan guru sesuai spesialisnya pada waktu melaksanakan pembelajaran.

\section{DAFTAR PUSTAKA}

Arikunto. S. (2009). Dasar-Dasar Evaluasi Pendidikan. Bina Aksara.Jakarta

BSNP. (2006 ). Standar Kompetensi dan Kompetensi Dasar SMP.BSNP.Jakarta

Buddin, R. dan Zamarro, G. 2009. Teacher Qualifications and Student Achievement in Urban Elementary Schools.http://www.rand.org/content/da m/rand/pubs/reprints/2010/RAND_RP1 410.pdf, diakses 2 April 2015. 


\section{Jurnal Serunai Ilmu Pendidikan \\ Vol.6, No.1, Juni 2020 \\ e-ISSN $2621-2676$ \\ p-ISSN 2528 - 0775}

Cochran, K.F.,DeRuiter, J.A., dan King, R.A. 1993. Pedagogical Content Knowing: An Integrative Model for Teacher Preparation. Journal of Teacher Education, 44 (4): 263-272.

Depdiknas, 2003, Kurikulum 2004 SMA.

Pedoman Khusus Pengembangan

Silabus dan penilaian. Mata pelajaran

Biologi. Jakarta. Depdiknas.

Afni, Khairina. 2019. Pengaruh Penggunaan Media Animasi Terhadap Hasil Belajar Biologi Siswa Pada Materi Pokok Sistem Reproduksi Pada Manusia Di Kelas Xi Ipa Sma Negeri 5

Binjai. ejournal.stkipbudidaya.ac.id/index.php /ja/article/view/224. J. Serunai Ilmiah Pendidikan Vol. 5 No.2 . Hal:95-105

Permendiknas No. 22.(2006).Standar Isi.Jakarta.

Peraturan Pemerintah No.19.(2005). Standar Nasional Pendidikan. Jakarta

Permendiknas No. 16.(2007).Standar Kualifikasi Akademik dan Kompetensi Guru.Jakarta

Permendiknas No. 41.(2007).Standar Proses.Jakarta

Permendiknas No. 20 .(2007). Standar Penilaian Pendidikan.Jakarta
Purwianingsih, W., Rustaman, N.Y., dan Redjeki, S. 2010. Pengetahuan Konten Pedagogi $(P C K)$ dan Urgensinya dalam Pendidikan Guru. Jurnal Pengajaran MIPA, 15 (2): 87-94.

Rahadyanti,A.(2010). IPA Terpadu Hadapi Tantangan (2010) http://ktspsekolah.blogspot.com/2010/ 02/konsep-pembelajaran-ipaterpadu.html ( accessed 11 April 2010, 11:07 WIB)

Sitepu, DRB. 2017. Analisis Kesulitan Guru IPA Terpadu dalam Mengajar Materi Biologi di SMP Negeri Kota Binjai T.P. 2010/2011. Prosiding Seminar Nasional Dies Natalis ke-27, STKIP Budidaya Binjai.

Sitepu, DRB. 2019. Perbandingan Hasil Belajar Siswa Dengan Menggunakan Media Audiovisual Dan Tanpa Media Audiovisual Pada Materi Struktur Dan Fungsi Sel Sebagai Unit Terkecil Kehidupan Di Kelas XI SMA Swasta Esa Prakarsa T.A 2018/2019. J. Serunai Ilmu Pendidikan Vol.5. No.1, STKIP Budidaya, Binjai.

Undang-Undang RI No. 20.(2003), Sistem Pendidikan Nasional.CV Medya Duta.Jakarta.

Unesco. 2010. Current Challenges in Basic Science Education. Paris: Unesco Education Sector. 